\title{
Stabilitas Hasil dan Ketahanan Lima Genotipe Melon (Cucumis melo L.) yang Dibudidayakan di Tiga Ketinggian Tempat
}

\section{Yield Stability and Resistance of Five Melon Genotypes (Cucumis melo L.) Cultivated on Three Altitude Areas}

\author{
Muhammad lqbal' ${ }^{1}$, Erlina Ambarwati ${ }^{*}$, dan Suyadi Mitrowihardjo2) \\ 1) Program Studi Agronomi, Fakultas Pertanian, Universitas Gadjah Mada \\ 2) Departemen Budidaya Pertanian, Fakultas Pertanian, Universitas Gadjah Mada \\ *) Penulis untuk korespondensi E-mail: erlina.a@ugm.ac.id
}

\begin{abstract}
The study was conducted to determine the yield stabilities of five melon varieties tested at three altitude areas and to obtain a variety of melon whose yield and stability exceed at three altitude areas. The study examined five melon varieties, namely 'Golden Aroma', 'Ladika', King Melon, Bravo, and M19 at three altitudes, namely Jombang (lowland 52 m

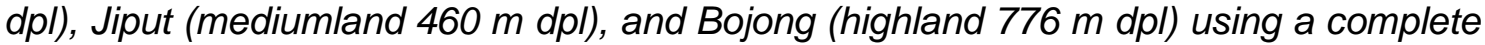
randomized block design (RAKL) with four replicates (blocks). The study was conducted during the rainy season in October 2016-January 2017 (in Jombang), November 2016February 2017 (in Jiput), and March $2017-J u n e 2017$ (in Bojong). The results showed that the varieties that had yield per hectare and genotype resistance to the environment exceeded the general average were the varieties of King Melon and Bravo, although both of them were unstable at three altitude areas. Average yield per hectare for King Melon (19.33 ton/ha) and Bravo (18.21 ton/ha) and genotype resistance to the environment for King Melon (65.42\%) and Bravo (56.25\%) were superior to the commercial varieties of 'Golden Aroma' and 'Ladika' and able to compete with national melon yields in 2013 (17.71 ton/ha) and 2014 (18.37 ton/ha).
\end{abstract}

Keywords: melon varieties, yield, resistancy, stability

\section{INTISARI}

Penelitian dilakukan untuk mengetahui stabilitas hasil lima varietas melon yang diuji di tiga ketinggian tempat dan untuk mendapatkan varietas harapan melon yang hasil dan stabilitasnya unggul di berbagai ketinggian tempat tanam. Penelitian yang menguji lima varietas melon, yaitu 'Golden Aroma' dan 'Ladika' (varietas pembanding), King Melon, Bravo dan M19 (varietas harapan) di tiga ketinggian tempat, yaitu Jombang (dataran rendah $52 \mathrm{~m}$ dpl), Jiput (dataran sedang $460 \mathrm{~m}$ dpl), dan Bojong (dataran tinggi $776 \mathrm{~m}$ dpl) menggunakan rancangan acak kelompok lengkap (RAKL) dengan empat ulangan (blok). Penelitian ini dilakukan selama musim hujan di bulan Oktober 2016-Januari 2017 (di Jombang), November 2016-Februari 2017 (di Jiput), dan Maret 2017-Juni 2017 (di Bojong). Hasil penelitian menunjukkan bahwa varietas yang memiliki daya hasil per hektar dan ketahanan genotipe terhadap lingkungan melebihi rerata umumnya adalah varietas harapan King Melon dan Bravo, meski hasil keduanya tidak stabil di tiga ketinggian tempat. Rerata daya hasil per hektar untuk King Melon (19,33 ton/ha) dan Bravo (18,21 ton/ha) dan ketahanan genotipe terhadap lingkungan untuk King Melon 
$(65,42 \%)$ dan Bravo $(56,25 \%)$ lebih unggul dari varietas pembanding 'Golden Aroma' dan 'Ladika' serta mampu berkompetisi dengan hasil melon tingkat nasional tahun 2013 $(17,71$ ton/ha) dan tahun 2014 (18,37 ton/ha).

Kata kunci: varietas melon, daya hasil, ketahanan, stabilitas

\section{PENDAHULUAN}

Kebutuhan masyarakat terhadap konsumsi buah melon segar semakin meningkat. Hal ini dikarenakan masyarakat telah menyadari khasiat dari jenis buah ini. Pessarakli (2016) menyebutkan satu diantara khasiat mengkonsumsi buah melon adalah menjadi sebab mengatasi sakit ginjal. Di sisi lain, ketersediaan buah melon nasional belum mencukupi permintaan sehingga impor ditingkatkan. Berdasarkan data statistik produksi hortikultura, produktivitas nasional komoditas melon pada tahun 2013 (17,71 ton/ha) menjadi (18,37 ton/ha) pada tahun 2014 (Anonim, 2015). Nilai impor buah melon segar meningkat dari 30,06 ton (tahun 2015) menjadi 95,84 ton (tahun 2016) (Anonim, 2017). Satu diantara solusi adalah penerapan metode pemuliaan tanaman berupa metode introduksi untuk mengetahui stabilitas lima varietas melon yang diuji di tiga ketinggian tempat dan untuk mendapatkan varietas harapan melon yang hasil dan stabilitasnya unggul di berbagai ketinggian tempat tanam. Gomez \& Gomez (1995) memaparkan bahwa pengujian varietas melon harapan dilakukan di berbagai tempat tanam bersama dengan varietas yang umum ditanam di daerah setempat.

\section{BAHAN DAN METODE}

Penelitian ini dilakukan di tiga tempat tanam di Provinsi Banten, yaitu Jombang Cilegon (dataran rendah $52 \mathrm{~m} \mathrm{dpl}$ ), Jiput Pandeglang (dataran sedang $460 \mathrm{~m} \mathrm{dpl),} \mathrm{dan}$ Bojong Pandeglang (dataran tinggi 776 m dpl) selama bulan (Oktober 2016-Juni 2017). Bahan tanam yang digunakan adalah benih lima varietas melon hibrida. Kelimanya adalah varietas pembanding ('Golden Aroma' dan 'Ladika') serta varietas harapan (King Melon, Bravo, dan M19). Benih 'Golden Aroma' berasal dari PT. Known You Seed, Taiwan. Adapun selainnya berasal dari CV. Multi Global Agrindo, Karanganyar.

Prosedur umum budidaya melon diawali pengolahan lahan mulai dari pembajakan lahan sampai bedengan ditutupi plastik mulsa. Sepekan menjelang lahan ditanami, benih disemai. Media semai terdiri dari lapisan bawah (lempung) dan lapisan atas (serbuk gergaji bercampur pupuk organik). Benih disemai selama 7 hari yang kemudian dipindahtanamkan ke lahan. Bersamaan dengan itu, pembuatan dan pemasangan penyangga dari bambu pada bedengan dilakukan. Hasil semaian 
dipindahtanamkan ke lubang tanam sedalam $5 \mathrm{~cm}$. Kegiatan merompes dilakukan mulai pukul 09:00 WIB ketika sinar matahari terasa hangat karena luka yang basah pada organ tanaman akibat merompes berpeluang terinfeksi patogen. Pemberian pupuk nitrogen, fosfor, kalium (NPK) 16\%: 16\%: 16\% diaplikasikan pada fase vegetatif dengan dosis 3 gram per tanaman sejak umur 22 hari setelah semai setiap lima hari sampai umur 52 hari setelah semai. Adapun pupuk kalium nitrat $\left(\mathrm{KNO}_{3}\right)$ dan mono kalium phosphate (MKP) diaplikasikan dengan dosis 2 gram per tanaman sejak umur 53 hari setelah semai sampai menjelang panen.

Di Jombang, banyak ditemukan hama tikus (Rattus argentiventer) dan hama thrips (Thrips palmi) serta penyakit kresek daun (patogen Pseudoperonospora cubensis). Di Jiput, banyak ditemukan hama tikus (Rattus argentiventer), penyakit antraknosa (patogen Colletotrichum orbiculare), penyakit busuk buah oleh larva lalat buah (Bactrocera cucurbitae), dan penyakit busuk pangkal batang (patogen Didymella bryoniae). Adapun tempat tanam di Bojong banyak ditemukan hama pengorok daun (Liriomyza sp.), penyakit busuk pangkal batang (patogen Didymella bryoniae), penyakit kerdil virus (vektor Aphis gossypii), dan penyakit busuk buah (patogen Phytophthora sp.).

Panen dilakukan sebelum umur tanaman mencapai 70 hari setelah semai saat serempak $50 \%$ buah melon dari total tanaman melon telah matang. Diantara indikator matangnya buah melon adalah perubahan warna menjadi kekuning-kuningan dan beraroma harum. Pemetikan buah dilakukan pada pagi hari karena suhu yang tinggi ketika pemetikan dapat merusak kualitas buah. Buah hasil panen dikumpulkan di dalam ruangan khusus beralas kain terpal dan jerami padi kering untuk menghindari kerusakan buah melon karena benturan dan busuk karena lembap. Standar kualitas buah melon yang layak komersial (grade A) adalah memiliki kualitas internal yang baik, yaitu tidak terlalu matang, bentuk buah yang ideal, net terbentuk tebal merata, dan bebas dari kerusakan pada buah. Buah melon yang tidak termasuk grade $\mathrm{A}$ umumnya memiliki perkembangan net yang tidak sempurna dan cacat karena serangan ulat, serta perkembangan buah tidak normal karena tanaman terserang organisme pengganggu tanaman.

Analisis varian dibuat untuk tiap tempat tanam. Model analisis varian untuk tiap tempat tanam, selanjutnya dilakukan uji homogenitas varian galat analisis varian tiap tempat tanam dengan menggunakan uji homogenitas Bartlett. Jika $F_{\text {hitung }}>F_{\text {tabel }}$ maka varian galat tidak homogen sehingga perlu ditransformasi data. Jika $F_{\text {hitung }}<F_{\text {tabel }}$ maka 
varian galat homogen. Jika data sudah homogen, selanjutnya dilakukan analisis varian gabungan.

\section{HASIL DAN PEMBAHASAN}

Pada Tabel 1, variabel pengamatan daya hasil per hektar varietas-varietas melon tidak terdapat pengaruh interaksi yang nyata dengan ketiga tempat tanamnya. Hal tersebut berarti bahwa daya hasil per hektar varietas-varietas melon mempunyai tanggapan yang stabil di setiap tempat tanamnya. Pada analisis varian tersebut, daya hasil per hektar dari kelima varietas melon tidak dipengaruhi secara nyata oleh tempat tanam di Jombang, Jiput, dan Bojong. Tidak adanya pengaruh interaksi antara varietas dengan tempat tanam menunjukkan bahwa tidak ada perbedaan tanggapan atau respon daya hasil per hektar varietas-varietas melon terhadap perubahan tempat tanam. Namun, pengaruh varietas dan tempat berbeda nyata terhadap variabel tersebut.

Tabel 1. Analisis varian daya hasil per hektar

\begin{tabular}{lccc}
\hline \multicolumn{1}{c}{ Sumber ragam } & $\begin{array}{c}\text { Derajat } \\
\text { bebas }\end{array}$ & Jumlah kuadrat & Kuadrat tengah \\
\hline Blok & 1 & 0,10 & $0,10 \mathrm{~ns}$ \\
Varietas & 4 & 5,35 & $1,34^{*}$ \\
Tempat & 2 & 32,11 & $16,05^{\star}$ \\
Varietas*tempat & 8 & 1,63 & $0,20 \mathrm{~ns}$ \\
Galat gabungan & 44 & 7,22 & 0,16 \\
\hline Corrected total & 59 & 46,42 & \\
CV\% & 8,80 & & \\
\hline
\end{tabular}

Pada Tabel 2, rerata daya hasil per hektar paling tinggi dimiliki oleh varietas melon harapan King Melon dengan nilai 19,33 ton/ha yang pengaruhnya berbeda nyata dengan 'Golden Aroma', 'Ladika', dan M19, tetapi tidak berbeda nyata dengan Bravo. Di sisi lain, rerata daya hasil per hektar 'Golden Aroma' (14,57 ton/ha) tergolong rendah di bawah rerata umum daya hasil per hektar (16,21 ton/ha). Varietas-varietas harapan melon terhadap tempat tanamnya memiliki rerata daya hasil per hektar dengan nilai 16,21 ton/ha.

Tabel 2. Rerata daya hasil per hektar (ton/ha) lima varietas melon di tiga ketinggian tempat

\begin{tabular}{lcccc}
\hline \multirow{2}{*}{ Genotipe } & \multicolumn{4}{c}{ Daya hasil per hektar (ton/ha) } \\
\cline { 2 - 5 } & Jombang & Jiput & Bojong & Rerata \\
\hline 'Golden Aroma' & 12,14 & 23,72 & 7,84 & $14,57 \mathrm{~b}$ \\
'Ladika' & 13,42 & 19,12 & 10,03 & $14,19 \mathrm{~b}$ \\
King Melon & 17,91 & 28,13 & 11,95 & $19,33 \mathrm{a}$ \\
Bravo & 17,00 & 24,36 & 13,27 & $18,21 \mathrm{a}$ \\
M19 & 14,70 & 20,36 & 9,16 & $14,74 \mathrm{~b}$ \\
\hline Rerata umum & $15,04 \mathrm{q}$ & $23,14 \mathrm{p}$ & $10,45 \mathrm{r}$ & $16,21(-)$ \\
Indeks lokasi & $-1,20$ & 6,90 & $-5,80$ & CV 8,09\% \\
\hline
\end{tabular}


Pada Tabel 2, tempat tanam Jiput memiliki rerata daya hasil per hektar sebesar 23,14 ton/ha yang tertinggi dan berbeda nyata terhadap tempat tanam Jombang dan Bojong. Berdasarkan data statistik produksi hortikultura, produktivitas nasional komoditas melon pada tahun 2013 (17,71 ton/ha) menjadi (18,37 ton/ha) pada tahun 2014 (Anonim, 2015). Rerata produktivitas buah melon berada dalam rentang (15-20) ton/ha (Pessarakli, 2016). Bila dibandingkan dengan produktivitas hasil penelitian ini, rerata daya hasil per hektar varietas-varietas melon 'Golden Aroma' (14,57 ton/ha), 'Ladika' (14,19 ton/ha), King Melon (19,33 ton/ha), Bravo (18,21 ton/ha), dan M19 (14,74 ton/ha). Dengan demikian, rerata daya hasil per hektar varietas harapan King Melon dan Bravo telah memenuhi produktivitas melon nasional.

Pengamatan daya hasil per hektar menunjukkan bahwa tidak ada interaksi tempat dengan varietas, maka varietas yang diuji di berbagai tempat, kemampuan daya hasilnya tidak jauh berbeda pada setiap tempat pengujian. Hal ini berarti juga hasil tertinggi suatu varietas pada suatu lingkungan tertentu belum tentu memberikan hasil tertinggi pula pada lingkungan yang berbeda.

Pada Tabel 3, analisis varian ketahanan genotipe terhadap lingkungan dengan metode Eberhart dan Russell (1966). Hasil menunjukkan ada beda nyata antara varietas melon dengan tempat linearnya. Hal ini berarti koefisien dari ketahanan genotipe terhadap lingkungan varietas melon yang diregresikan dengan tempat tanam memiliki nilai yang berbeda nyata antara varietas satu dengan yang lainnya.

Tabel 3. Analisis varian ketahanan genotipe terhadap lingkungan

\begin{tabular}{lccc}
\multicolumn{1}{c}{ Sumber ragam } & $\begin{array}{c}\text { Derajat } \\
\text { bebas }\end{array}$ & Jumlah kuadrat & Kuadrat tengah \\
\hline Blok & 1 & 0,08 & $0,08 \mathrm{~ns}$ \\
Tempat (linier) & 2 & 87,45 & $43,72^{*}$ \\
Varietas & 4 & 59,52 & $14,88^{*}$ \\
Varietas*tempat (linier) & 8 & 7,80 & $1,00^{*}$ \\
Simpangan gabungan & 15 & 155,05 & $10,34^{*}$ \\
Galat gabungan & 44 & 3,51 & 0,08 \\
\hline Corrected total & 59 & 158,55 & \\
CV\% & 4,17 & & \\
\hline
\end{tabular}

Eberhart dan Russell (1966) mengungkapkan bahwa nilai $\beta \boldsymbol{i}$ (koefisien regresi) yang sama dengan satu $(\beta \boldsymbol{i}=1)$ menunjukkan bahwa varietas tersebut stabil (tidak berinteraksi dengan tempat tanam atau tidak respon terhadap peningkatan kualitas tempat tanam). Varietas yang memiliki $S d i^{2}$ (simpangan regresi) sama dengan nol $\left(S d i^{2}=0\right)$, maka varietas tersebut tidak berinteraksi dengan tempat tanam. Namun, apabila nilai simpangan regresinya tidak sama dengan nol $\left(S d i{ }^{2} \neq 0\right)$, varietas berinteraksi 
dengan tempat tanam, meskipun koefisien regresinya sama dengan satu $(\beta \boldsymbol{i}=1)$. Nilai koefisien regresi dan simpangannya disajikan dalam Tabel 4.

Pada Tabel 4, 'Golden Aroma' di Bojong memiliki rerata ketahanan genotipe terhadap lingkungan yang terendah (15,00\%) dibandingkan 'Ladika', King Melon, Bravo, dan M19 serta berbeda pengaruhnya secara nyata dengan seluruh varietas di ketiga tempat tanam. Sebaliknya, Bravo di Jiput sebagai varietas yang memiliki rerata ketahanan genotipe terhadap lingkungan tertinggi $(90,00 \%)$ dan tidak berbeda nyata dengan King Melon di Jiput (86,25\%).

Nilai koefisien regresi Bravo berbeda nyata dengan satu $(\beta i>1)$ dan koefisien regresi untuk 'Golden Aroma' berbeda nyata dengan satu $(\beta \boldsymbol{i}<1)$, sedangkan pada 'Ladika', King Melon, dan M19 tidak berbeda nyata dengan satu atau mendekati satu $(\beta \approx 1)$. Adapun nilai simpangan regresi kelima varietas 'Golden Aroma', 'Ladika', King Melon, Bravo, dan M19 berbeda nyata dengan nol ( $\left.S d i^{2} \neq 0\right)$. Pada Tabel 4 , bila nilai koefisien regresi dan simpangan regresi saling dihubungkan, varietas Bravo memiliki nilai koefisien regresi yang berbeda nyata dari satu $(\beta i>1)$ dan simpangan regresi yang juga berbeda nyata dari nol $\left(S d i^{2} \neq 0\right)$. Hal ini menunjukkan Bravo tidak stabil (ada interaksi berupa respon terhadap peningkatan kualitas lingkungan). Eberhart dan Russell (1966) menyatakan bahwa suatu genotipe dikatakan stabil apabila mempunyai koefisien regresi mendekati atau sama dengan satu $(\beta \boldsymbol{i}=1)$ dan simpangan regresi mendekati atau sama dengan nol $\left(S d^{2}=0\right)$. Varietas harapan Bravo mempunyai koefisien regresi yang berbeda nyata dari satu $(\beta i>1)$ sehingga beradaptasi dengan baik pada tempat tanam yang produktif. Sunyoto dan Budiyanti (2010) mengungkapkan genotipe yang mempunyai koefisien regresi $\beta i>1$ akan beradaptasi dengan baik pada lingkungan yang produktif (lingkungan yang medukung). Di sisi lain, rerata ketahanan genotipe terhadap lingkungan pada Bravo $(56,25 \%)$ berada di atas rerata umum ketahanan genotipe terhadap lingkungan $(47,92 \%)$.

Tabel 4. Ketahanan genotipe terhadap lingkungan (\%), koefisien regresi dan simpangan regresi

\begin{tabular}{|c|c|c|c|c|c|c|}
\hline \multirow[b]{2}{*}{ Genotipe } & \multicolumn{4}{|c|}{ Ketahanan genotipe terhadap lingkungan (\%) } & \multirow{2}{*}{$\begin{array}{c}\text { Koefisien } \\
\text { regresi }\end{array}$} & \multirow{2}{*}{$\begin{array}{l}\text { Simpangan } \\
\text { regresi }\end{array}$} \\
\hline & Jombang & Jiput & Bojong & Rerata & & \\
\hline 'Golden Aroma' & $23,75 \mathrm{e}$ & $38,75 \mathrm{c}$ & $15,00 f$ & 25,83 & $0,79^{*}$ & $-0,48^{*}$ \\
\hline 'Ladika' & $37,50 \mathrm{c}$ & $70,00 \mathrm{~b}$ & $30,00 d$ & 45,83 & $1,02 \mathrm{~ns}$ & $15,02^{*}$ \\
\hline King Melon & $71,25 b$ & $86,25 a$ & $38,75 \mathrm{c}$ & 65,42 & $0,96 \mathrm{~ns}$ & $29,75^{\star}$ \\
\hline Bravo & $40,00 \mathrm{c}$ & $90,00 a$ & $38,75 \mathrm{c}$ & 56,25 & $1,19^{*}$ & $21,03^{*}$ \\
\hline M19 & $40,00 \mathrm{c}$ & $70,00 \mathrm{~b}$ & $28,75 d$ & 46,25 & $1,04 \mathrm{~ns}$ & $15,14^{*}$ \\
\hline Rerata umum & 42,50 & 71,00 & 30,25 & $47,92(+)$ & & \\
\hline Indeks lokasi & $-5,40$ & 23,00 & $-17,60$ & $\begin{array}{l}\text { CV } \\
4,09 \%\end{array}$ & & \\
\hline
\end{tabular}


Adapun 'Golden Aroma' memiliki koefisien regresi yang berbeda nyata dari satu $(\beta \boldsymbol{i}<1)$ dan simpangan regresi yang juga berbeda nyata dari nol $\left(S d i^{2} \neq 0\right)$. Hal ini menunjukkan 'Golden Aroma' tidak stabil baik di tempat tanam Jombang, Jiput, maupun Bojong. 'Golden Aroma' mempunyai koefisien regresi kurang dari satu $(\beta \boldsymbol{i}<1)$ sehingga beradaptasi dengan baik pada tempat tanam yang kurang atau tidak produktif. Sunyoto dan Budiyanti (2010) mengungkapkan bahwa genotipe yang mempunyai koefisien regresi $\beta \dot{i}<1$ akan beradaptasi dengan baik pada lingkungan yang marginal. Rerata ketahanan genotipe terhadap lingkungan 'Golden Aroma' $(25,83 \%)$ tergolong kriteria yang rentan dan berada di bawah rerata umum ketahanan genotipe terhadap lingkungan (47,92\%) (Tabel 4).

Berbeda dari Bravo dan 'Golden Aroma' yang memiliki koefisien regresi yang berbeda nyata dari satu $\left(\beta_{\neq} \neq 1\right)$ baik lebih $\left(\beta_{i}>1\right)$ maupun kurang dari satu $\left(\beta_{i}<1\right)$ serta simpangan regresi yang berbeda nyata dari nol $\left(S_{d i}{ }^{2} \neq 0\right)$, varietas 'Ladika', King Melon, dan M19 memiliki koefisien regresi yang tidak berbeda nyata atau sama dengan satu $\left(\beta_{i}=1\right)$ dan simpangan regresi yang berbeda nyata dari nol $\left(S_{d i}{ }^{2} \neq 0\right)$. Hal ini menunjukkan 'Ladika', King Melon, dan M19 tidak stabil (ada pengaruh interaksi terhadap perbedaan ketinggian tempat tanam). Eberhart dan Russell (1966) mengungkapkan bahwa apabila nilai simpangan regresinya tidak sama dengan nol $\left(S_{d i}^{2} \neq 0\right)$, varietas berinteraksi dengan tempat tanam, meskipun koefisien regresinya tidak berbeda nyata dengan satu $\left(\beta_{i=1}\right)$.

Varietas memberikan ketahanan genotipe yang tinggi saat ditanam di lingkungan yang baik, sedangkan varietas memberikan ketahanan genotipe yang rendah saat ditanam di lingkungan yang tidak mendukung seperti ketinggian tempat yang tidak sesuai syarat tumbuh tanaman. Hal ini sebagaimana yang dikemukakan Nasrullah (1981) bahwa bila tidak terjadi interaksi antara genotipe dan lingkungan, penentuan genotipe dapat dilakukan dengan memilih genotipe-genotipe dengan hasil yang lebih tinggi dari rerata hasil. Dengan demikian, varietas melon yang memiliki rerata ketahanan genotipe terhadap lingkungan di atas rerata umum (47,92\%) adalah King Melon $(65,42 \%)$ dan Bravo $(56,25 \%)$. Adanya interaksi pada 'Ladika', King Melon, dan M19 terhadap ketiga tempat tanam ditunjukkan dengan nilai rerata ketahanan genotipe terhadap lingkungan, yaitu 'Ladika' (37,50\% di Jombang, 70,00\% di Jiput, 30,00\% di Bojong), King Melon (71,25\% di Jombang, 86,25\% di Jiput, 38,75\% di Bojong), dan M19 (40,00\% di Jombang, $70,00 \%$ di Jiput, $28,75 \%$ di Bojong) yang berbeda nyata antartempat tanamnya (Tabel 4).

Dari uji stabilitas Eberhart dan Russell (1966) terhadap daya hasil per hektar dan ketahanan genotipe terhadap lingkungan lima varietas melon di tiga tempat tanam, 
varietas yang dianggap baik adalah yang memiliki rerata hasil tinggi, koefisien regresi $\left(\beta_{i}\right)$ tidak berbeda nyata dari satu $\left(\beta_{i}=1\right)$ dan simpangan regresi $\left(S_{d i}{ }^{2}\right)$ sekecil mungkin mendekati nol $\left(S_{d i}{ }^{2}=0\right)$. Suatu varietas dengan hasil tinggi dan memenuhi kedua kriteria tersebut memiliki penampilan yang baik di semua lingkungan. Dalam penelitian ini, kelima varietas melon tidak ada yang memenuhi secara sempurna kriteria-kriteria tersebut, tetapi King Melon dan Bravo lebih unggul daripada tiga varietas uji lainnya.

\section{KESIMPULAN}

Varietas yang memiliki daya hasil per hektar dan ketahanan genotipe terhadap lingkungan melebihi rerata umumnya adalah varietas harapan King Melon dan Bravo, meski hasil keduanya tidak stabil di tiga ketinggian tempat. Rerata daya hasil per hektar untuk King Melon (19,33 ton/ha) dan Bravo (18,21 ton/ha) dan ketahanan genotipe terhadap lingkungan untuk King Melon (65,42\%) dan Bravo (56,25\%) lebih unggul dari varietas pembanding 'Golden Aroma' dan 'Ladika' serta mampu berkompetisi dengan hasil melon tingkat nasional tahun 2013 (17,71 ton/ha) dan tahun 2014 (18,37 ton/ha).

\section{UCAPAN TERIMA KASIH}

Ucapan terimakasih penulis sampaikan kepada kedua orangtua, Dinas Pertanian Cilegon, Kelompok Tani Taruna Mekar Pandeglang, Kelompok Tani Palered Pandeglang, dan CV. Multi Global Agrindo Karanganyar yang telah memberikan bantuan dana dan fasilitas memadai selama penelitian berlangsung.

\section{DAFTAR PUSTAKA}

Anonim. 2015. Statistik produksi hortikultura tahun 2014. $<$ http://hortikultura.pertanian.go.id/wp-content/uploads/2016/02/StatistikProduksi-2014.pdf>. Diakses 18 September 2017.

Anonim. 2017. Basis data ekspor dan impor buah melon segar. <http://database. pertanian.go.id/ eksim2012/index ori.php>. Diakses 27 Maret 2017.

Eberhart, S. A. and W. A. Russell. 1966. Stability parameters for comparing varieties. Crop Sci. $6: 36-40$.

Gomez, K. A. and A. A. Gomez. 1995. Prosedur Statistika untuk Penelitian Pertanian. Edisi ke-2. Universitas Indonesia Press, Jakarta.

Nasrullah. 1981. A modified procedure for identifying varietal stability. Agric. Sci.546: 153-159.

Pessarakli, M. 2016. Handbook of Cucurbits : Growth, Cultural Practices, and Physiology. CRC Press, New York. 
Muhammad lqbal et al., / Vegetalika. 2018. 7(2): 30-38

Sunyoto dan T. Budiyanti. 2010. Stabilitas Pertumbuhan Vegetatif Lima Genotipe Pepaya (Carica papaya) di Tiga Lingkungan Tumbuh. Seminar Nasional Program dan Strategi Pembangunan Buah Nusantara, Solok. 